\title{
Micro-environmental factors in the survival of human B-lymphoma cells
}

\author{
JM Levens ${ }^{1}$, J Gordon ${ }^{2}$ and CD Gregory ${ }^{\star 1}$ \\ 1 Institute of Cell Signalling and School of Biomedical Sciences, University of \\ Nottingham Medical School, Queen's Medical Centre, Nottingham, NG7 2UH, \\ UK \\ 2 MRC Centre for Immune Regulation, University of Birmingham Medical \\ School, Birmingham B15 2TT, UK \\ * Corresponding author: CD Gregory, Institute of Cell Signalling and School of \\ Biomedical Sciences, University of Nottingham Medical School, Queen's \\ Medical Centre, Nottingham, NG7 2UH, UK, Tel: +44 115970 9370; Fax: +44 \\ 115970 9926; E-mail: Chris.Gregory@nottingham.ac.uk
}

Received 14.7.99; revised 9.11.99; accepted 11.11.99

Edited by M Piacentini

\begin{abstract}
Burkitt lymphoma $(B L)$ cells retain a high inherent propensity to undergo apoptosis indicating that net growth of the tumour population in vivo is likely to be influenced profoundly by its micro-environment. Here we investigate micro-environmental factors that affect BL-cell survival in vitro. We show that survival, and consequently net production, of tumour cells is enhanced by autocrine factors and, to a greater extent, by paracrine factors provided by relevant stromal elements of the tumour (fibroblasts and follicular dendritic cells) and by macrophages. Promotion of BL-cell survival by paracrine elements was mediated by cell/cell contact and by short-range soluble factor(s). IL-4, IL-10 and TNF- $\alpha$ promoted, whereas TGF- $\beta 1$ inhibited, tumour-cell production. Macrophages engaged in phagocytosis of apoptotic BL cells were less effective than untreated macrophages in supporting net expansion of $B L$ populations. These results suggest that the net production of tumour cells in BL is supported by multiple micro-environmental factors that modulate apoptosis. Cell Death and Differentiation (2000) 7, 59-69.
\end{abstract}

Keywords: apoptosis; B-cell; Burkitt; lymphoma; micro-environment; macrophage

Abbreviations: bFGF, basic fibroblast growth factor; BL, Burkitt lymphoma; CD40L, CD40 ligand; EGF, epidermal growth factor; GM-CSF, granulocyte-macrophage colony-stimulating factor; HFF, human foetal fibroblast; IGF, insulin-like growth factor; IL, interleukin; LPS, lipopolysaccharide; PDGF, platelet-derived growth factor; TGF, transforming growth factor; TNF, tumour necrosis factor

\section{Introduction}

Net growth in cell populations is governed by factors that regulate (1) cell-cycle entry, progression or exit and (2) apoptosis. Paradoxically, oncogene activity can lead not only to increased rates of cell-cycle entry and progression but also to increased susceptibility to apoptosis (reviewed in ${ }^{1}$ ). c-Myc, for example, appears to drive both proliferation and apoptosis through common properties that are required for its DNAbinding and transcriptional-regulatory activities, the proliferative response being dependent upon the presence of additional signals derived from receptors for cell-growth/ survival factors. ${ }^{2,3}$ Availability of apoptosis-inhibiting signals derived from the micro-environment of tumours is therefore potentially of great significance to net tumour growth. Little information, however, is currently available on the nature of such survival signals. Here we investigate this question in relation to Burkitt lymphoma (BL).

$\mathrm{BL}$ is a monoclonal B-cell malignancy characterised by translocations resulting in the juxtapositioning of c-myc to immunoglobulin heavy-chain or light-chain loci $(t(8 ; 14)$, $t(2 ; 8)$ or $t(8 ; 22)$ translocations) (reviewed $\left.\mathrm{in}^{4}\right)$. The lymphoma probably arises at a germinal-center stage of B-cell development ${ }^{5,6}$ and vestiges of the phenotype of normal germinal-centre $B$ cells are retained by $B L$ tumour cells and by certain BL-derived cell lines. These features include (1) display of a specific pattern of cell-surface antigens $\left(\mathrm{CD} 10^{+} \mathrm{CD} 23^{-} \mathrm{CD} 39^{-} \mathrm{CD} 77^{+}\right)$that is restricted to germinal-center B cells, ${ }^{5,7,8}$ (2) presence of little or none of the cytoplasmic inhibitor of apoptosis, Bcl-2, ${ }^{9,10}$ and (3) a propensity to undergo apoptosis rapidly by default, ${ }^{11}$ a necessary property underlying normal physiological selection of germinal-centre cells. ${ }^{12}$ BL-derived cell lines that retain these features have been previously categorised as 'group I' lines. ${ }^{7,8}$ These lines used in early passage have provided important models for studies of $\mathrm{BL}$ in vitro that are likely to have in vivo relevance. In this study we use a group I BL cell line to model in vitro the responses of BL cells to micro-environmental factors.

In situ, BL tumour-cell populations show evidence both of rapid proliferation and of frequent apoptosis, a likely result of the deregulation of $\mathrm{c}-\mathrm{Myc}$ which drives not only proliferation but also apoptosis in BL tumour cells. ${ }^{13}$ Thus, in the histological picture of $\mathrm{BL}$, mitotic figures are readily apparent as is the pyknotic appearance of apoptotic cells and bodies and the apoptotic cell-derived debris contained within the numerous infiltrating 'starry sky' macrophages. ${ }^{14-17}$ Phagocytic clearance of apoptotic cells by macrophages is a highly efficient process which confounds accurate assessments of the rates of apoptosis in vivo. Apoptotic cells are only visible using standard histological methods for short periods since they are rapidly engulfed by macrophages (which can occur prior to many of the characteristic morphological changes ${ }^{18}$ ) and, once engulfed, are rapidly degraded such that they 
quickly become unrecognisable. ${ }^{19}$ Therefore, ready histological observation of free apoptotic cells and of numerous macrophages containing apoptotic debris, as observed in $\mathrm{BL}$, is evidence indeed of high-frequency apoptosis in situ. Freshly isolated BL cells and group I lines show a clear tendency to undergo apoptosis by default in vitro ${ }^{10,11,13,20}$ and the histological picture of $\mathrm{BL}$ indicates that this inherent apoptosis-susceptibility is only incompletely blocked in vivo. This suggests that autocrine or paracrine factors of limited availability in the micro-environment of the tumour are required to provide survival signals necessary for expansion of the tumour-cell population. In addition, there may be a delicate balance between pro- and anti-apoptotic microenvironmental factors that favours net tumour growth.

In this study we investigate the effects on BL-cell apoptosis of micro-environmental factors that have possible relevance to $\mathrm{BL}$ in vivo. We demonstrate (1) autocrine and (2) paracrine survival pathways, the latter stimulated by fibroblasts, follicular dendritic cells (the antigen-capturing cells of germinal centres) and macrophages. In addition, we show that certain soluble factors that are produced by macrophages (IL-10 and TNF- $\alpha$ ) or T cells (IL-4) can enhance BL-cell population expansion by promoting BL-cell survival. By contrast our observations indicate that TGF- $\beta 1$, which is known to be produced by macrophages that have phagocytosed apoptotic cells, ${ }^{21}$ inhibits BL-cell survival. Significantly, macrophages fed with apoptotic BL cells were less effective than their untreated counterparts in providing soluble factors that support BL-cell survival. Therefore, the tumour microenvironment in $\mathrm{BL}$ is likely to provide multiple signals that can contribute both positively and negatively to net tumour growth.

\section{Results}

\section{Autocrine/juxtacrine effects on survival of BL cells}

$\mathrm{BL}$ was modelled in these studies using a group I, biopsy-like line, L3055 in early passage. Initial experiments were undertaken to determine simply the extent to which homotypic interactions between BL cells modulated tumour cell survival. These effects of cell 'crowding' were studied both under optimal (in $10 \%$ serum) and suboptimal (1\% serum) conditions (Figure 1). Figure 1A shows the levels of apoptosis in L3055 BL-cell populations cultured in 1\% serum in vessels allowing settling of cells on flat plastic surfaces of relatively high $\left(25 \mathrm{~cm}^{2}\right)$ versus relatively low $\left(7.6 \mathrm{~cm}^{2}\right)$ area. As shown in Figure 1B, apoptosis was also monitored in L3055 cells cultured in $10 \%$ serum in round-bottomed versus flatbottomed (i.e. less crowded) culture wells. Each of these experimental approaches demonstrated that BL-cell survival was moderately enhanced under conditions in which cells were brought into closer vicinity with their neighbours. Thus, as the seeded concentration of L3055 cells was increased the proportion of apoptotic cells at the end of the culture period fell. Concentration of cells on a smaller flat area (Figure 1A) or onto a curved culture surface (Figure $1 \mathrm{~B}$ ) resulted in reduction in apoptosis at lower cell numbers as compared with cells cultured under less crowded conditions. Expression of $\mathrm{Bcl}-2$ in L3055 cells virtually abolished apoptosis in these cultures at all seeding concentrations tested (Figure 1A). These results show that BL-cell survival is supported by one or more autocrine/juxtacrine factors.

\section{Paracrine effects on survival of BL cells}

In order to determine possible effects of non-tumour cells of relevance to $\mathrm{BL}$, we co-cultured $\mathrm{L} 3055$ cells with various lineages representative of tumour-infiltrating or stromal cell types, specifically human foetal fibroblasts, a follicular dendritic cell line $\mathrm{HK}^{22}$ human monocyte-derived macrophages and, to emulate an activated-T-cell-derived signal (since activated $\mathrm{T}$ cells are also known to infiltrate $\mathrm{BL}^{23}$ ), CD40-ligand (CD4OL)-expressing L-cells. ${ }^{24}$ As shown in Figures 2A and $3 \mathrm{~A}$, apoptosis in L3055 cells that were cocultured with fibroblasts, HK cells, macrophages, or CD40Lexpressing cells was substantially inhibited in all cases. In
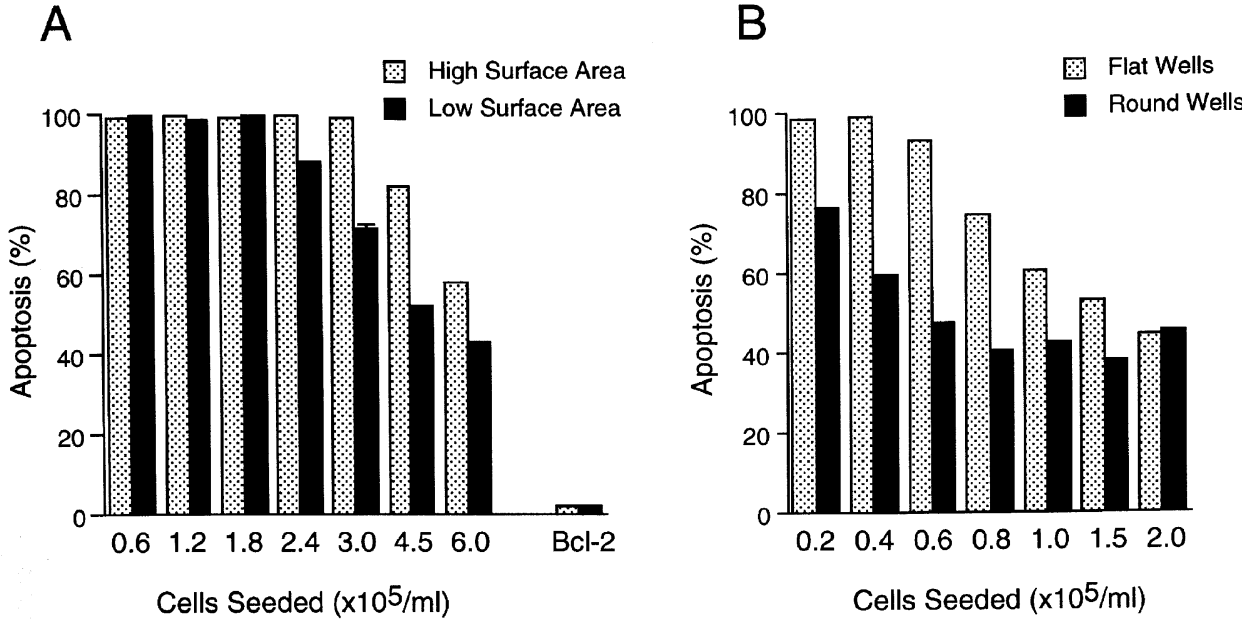

Figure 1 Autocrine survival of BL cells. L3055 cells were cultured at the indicated seeding cell concentrations and apoptosis assessed by light scatter analysis after the incubation period. (A) Incubation in flasks for $72 \mathrm{~h}$ allowing cells to settle on the surface of high $\left(25 \mathrm{~cm}^{2}\right.$ stippled bars) or low $\left(7.6 \mathrm{~cm}{ }^{2}\right.$ filled bars) relative area. Transfectants expressing high levels of Bcl-2 are shown for comparison. Means \pm S.D. of triplicate samples. (B) Incubation in flat- (stippled bars) or round(filled bars) bottomed wells for $96 \mathrm{~h}$. Both experiments representative of three similar 
parallel, total yields of L3055 cells were markedly enhanced by co-culture with fibroblasts, HK cells or macrophages (Figures 2B and $3 \mathrm{~B}$ ), indicating that enhanced cell survival was accompanied by expansion of the surviving cell population. By contrast, co-culture with CD40L-expressing $\mathrm{L}$ cells inhibited BL-cell expansion (Figure $2 \mathrm{~B}$ ). This resulted from a change in BL-cell phenotype that includes cell-growth arrest (Figures 4 and 5).

Under these conditions in which paracrine survival effects were substantial, no autocrine/juxtacrine effects on
BL-cell survival were demonstrable. Furthermore, the results of both Figures 2 and 3 show that apoptosissusceptibility of L3055 cells cultured on supporting cells of fibroblast, follicular dendritic cell, and macrophage origin is markedly lower than that of L3055 cells cultured alone. It appears, therefore that these paracrine/juxtacrine survival signals are more potent than the autocrine/juxtacrine signals described above.

Transwell cultures were set up to determine whether the pro-survival effects on L3055 cells of fibroblasts, HK cells
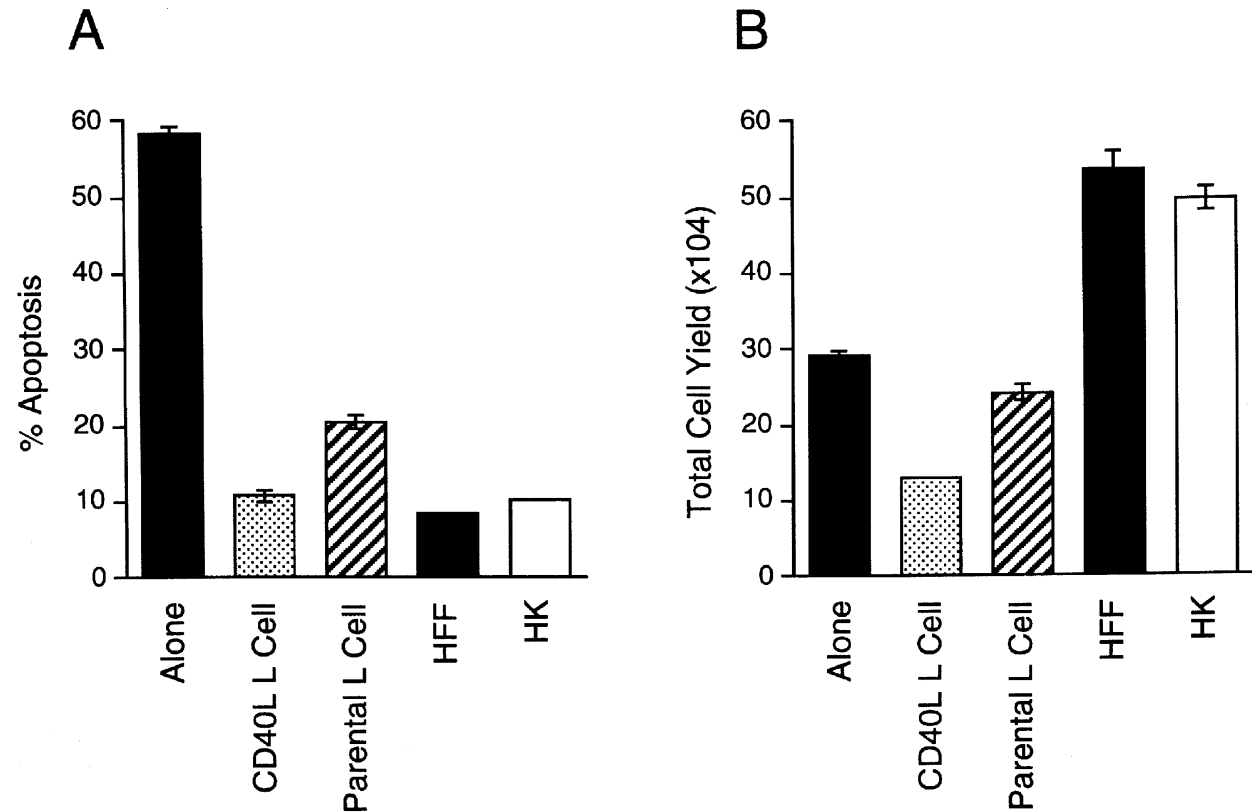

Figure 2 Paracrine survival and proliferation of BL cells. L3055 cells $\left(10 \mathrm{ml}, 2 \times 10^{5} \mathrm{ml}\right)$ were cultured in $25 \mathrm{~cm}^{2}$ flasks either alone or in direct contact with the indicated cells for $72 \mathrm{~h}$ after which \% apoptosis (A) and total cell yield (B) were assessed. Means \pm S.D. of duplicate samples. CD40L: CD40-ligand, HFF: human foetal fibroblasts, HK: follicular dendritic cell line. Experiment representative of three similar

A

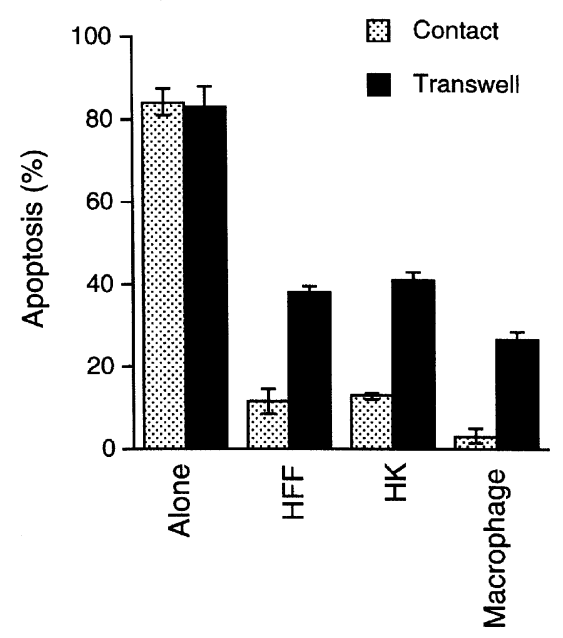

B

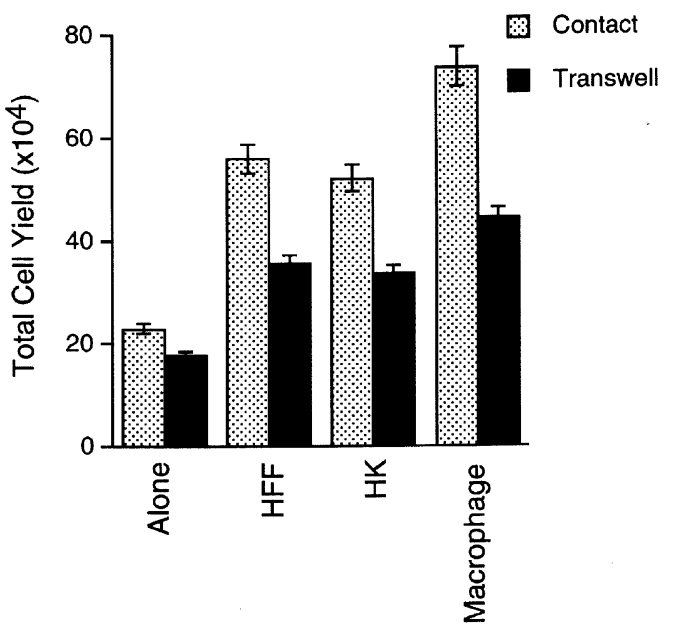

Figure 3 Paracrine support of BL-cell survival and proliferation by soluble factors. L3055 cells were cultured in the presence or absence of the indicated 'feeder' cells either in direct contact (stippled bars) or in transwells containing $0.4 \mu \mathrm{m}$ pore membranes. After $96 \mathrm{~h}, \%$ apoptosis (A) and total cell yield (B) were assessed. Means \pm S.D. of quadruplicate samples. Experiment representative of four similar 
CD11a

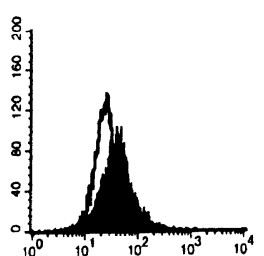

HFF
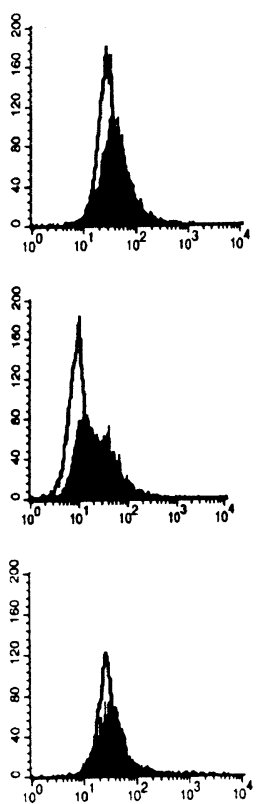

Parental

$L$ cell
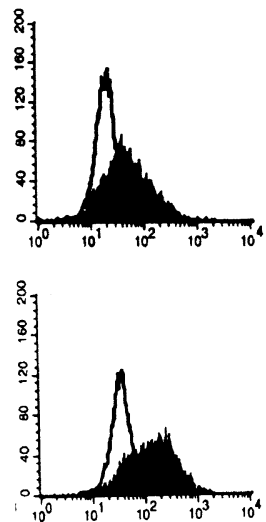
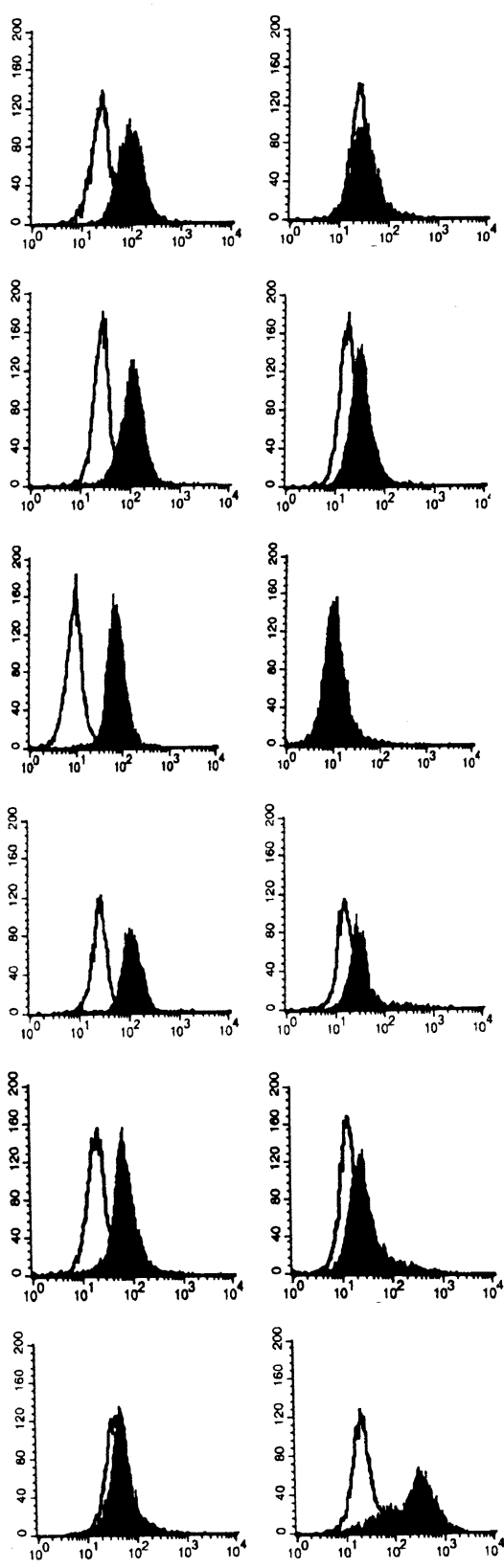

CD77

CD95
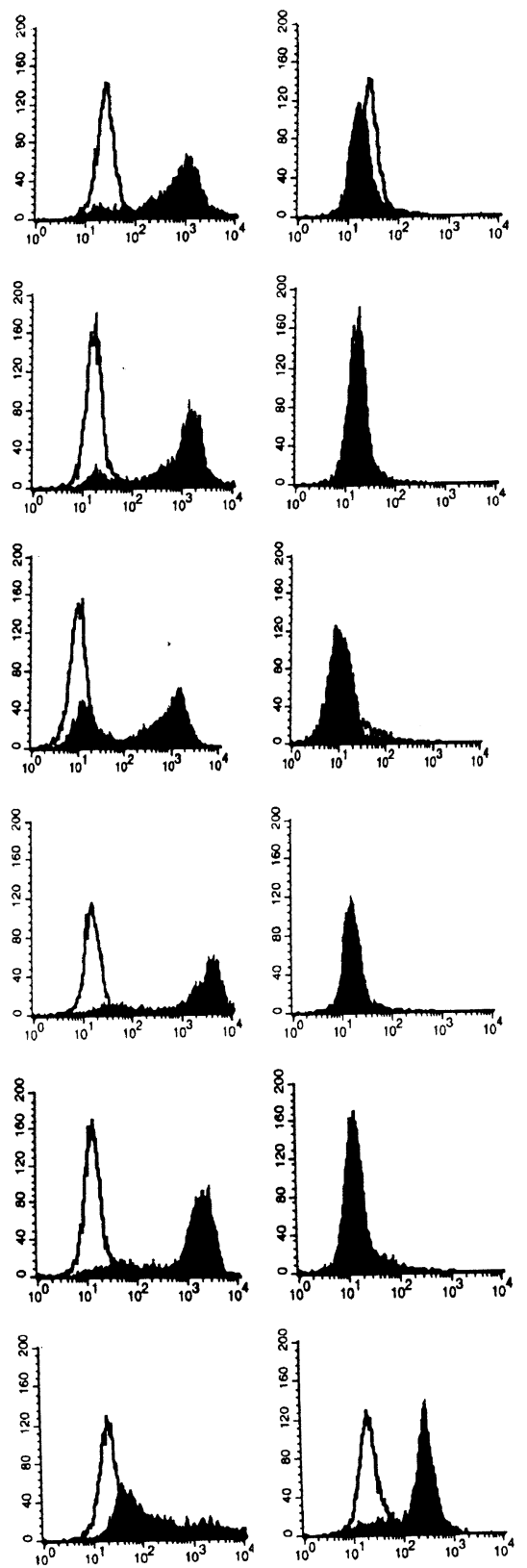

Figure 4 Changes in surface phenotype of BL cells cultured in the presence of CD40-ligand. L3055 cells were cultured for $72 \mathrm{~h}$ either alone or in direct contact with the indicated 'feeder' cells. Expression of the indicated cell-surface antigens was subsequently assessed by flow cytometry after indirect immunofluorescence staining. Histograms show relative cell number (ordinate) versus log fluorescence intensity (abscissa). Open histograms represent background staining (isotype control)

and macrophages resulted from factors that are diffusible through membranes containing $0.4 \mu \mathrm{m}$ pores. As shown in Figure 3A, survival of L3055 cells that were cultured either in direct contact with supporting cells or separated from them by cell-impermeable membranes was significantly better than that of $\mathrm{BL}$ cells cultured alone. BL-cell yields (Figure 3B) reflected these observations. However, both survival and yield of L3055 cells separated from supporting cells by membranes were significantly lower than that of L3055 cells cultured in direct contact with supporting cells. Supernatants isolated from cultures of fibroblasts, HK cells and macrophages failed to promote survival of L3055 cells (data not shown) indicating that the soluble factors which are functional in the transwell system either are active only over short-range (high local concentration) or are highly labile. These results demonstrate that multiple lineages of 

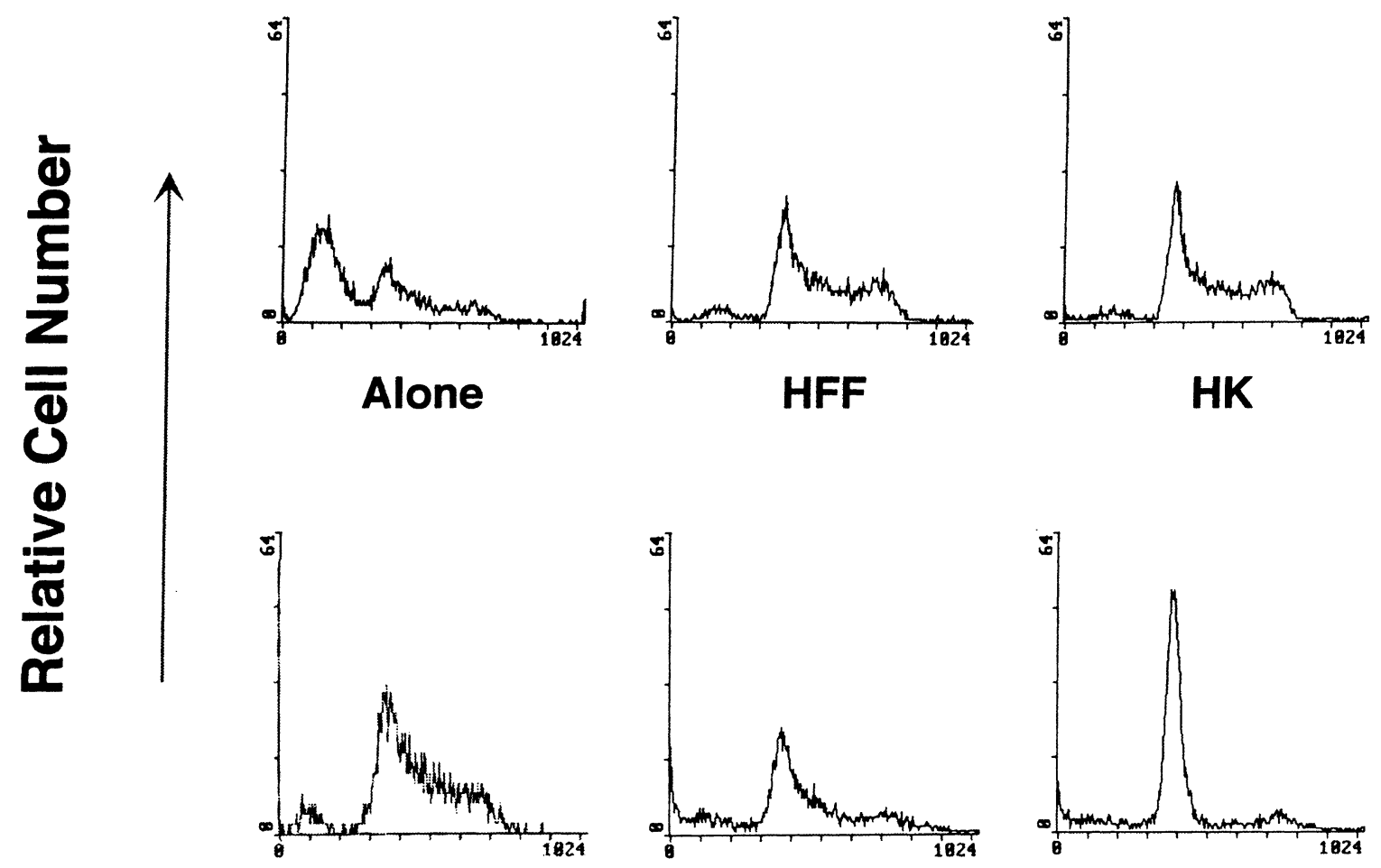

\section{Macrophage}

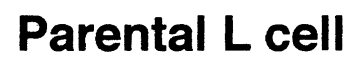

CD40L L cell

\section{Linear Fluorescence}

Figure 5 Cell-cycle change in BL cells cultured in the presence of CD40-ligand. L3055 cells were cultured for $72 \mathrm{~h}$ either alone or in direct contact with the indicated 'feeder' cells. Permeabilised BL cells were stained with propidium iodide and analyzed by flow cytometry. Proportions of cells in Sub G0, G0/G1, S and G2/M respectively were: Alone: 54.4, 25.2, 7.9, 12.5; HFF: 12.8, 42.7, 17.6, 26.9; HK: 12.0, 49.2, 16.1, 22.7; Macrophage: 9.5, 48.8, 21.2, 20.5; Parental L cell: 24.2, 41.8, 14.2, 19.8; CD40L L cell: $17.6,65.3,5.9,11.2$

supporting cells can provide paracrine survival signals, at least some of which are provided by soluble factor(s).

\section{Phenotypic stability of surviving BL cells}

We reasoned that paracrine survival pathways of potential significance to $\mathrm{BL}$ in vivo should promote survival and proliferation without change in group I phenotype, this being the phenotype of the tumour cells in vivo. Figure 4 shows immunophenotyping data comparing untreated L3055 cells with cells surviving co-cultivation with fibroblasts, HK cells, macrophages or CD40-ligand-expressing $L$ cells (together with parental $L$ cells). With the exception of those co-cultivated with CD40-ligand, no phenotypic changes in L3055 cells were noted. Cells exposed to CD40-ligand (both cell-bound (Figure 4) and soluble (data not shown) forms), showed several changes in cell-surface phenotype indicating substantial deviation from group I. Thus L3055 cells surviving co-culture with fibroblasts, HK cells or macrophages remained unchanged in their expression of CD10, CD11a, CD23, CD39, CD40, CD49d, CD54, CD77, CD95 and Bcl-2 compared with untreated cells (Figure 4 and data not shown). Furthermore BL cells did not acquire adhesive activity to fibroblasts, HK cells or macrophages during co-culture. By contrast, BL cells exposed to CD40-ligand displayed increases in CD11a (LFA-1 $\alpha$ ), CD54 (ICAM-1) and CD95 (Fas) together with a decrease in CD40 (Figure 4 and data not shown). The changes in cell-surface phenotype of CD40-ligand-exposed BL cells were also accompanied by cell-cycle arrest in $\mathrm{G} 1$ (Figures $2 \mathrm{~B}$ and 5), whereas $\mathrm{BL}$ cells co-cultured with fibroblasts, HK cells or macrophages remained in cycle (Figures $2 \mathrm{~B}, 3 \mathrm{~B}$ and 5), reflecting the status of the tumour cells in situ. Reduction in the sub-GO/ G1 population in the cell-cycle histograms (Figure 5) confirmed the pro-survival effects of the 'feeder' cells. These results suggest that fibroblasts, HK cells and macrophages may promote BL-cell survival by mechan- 


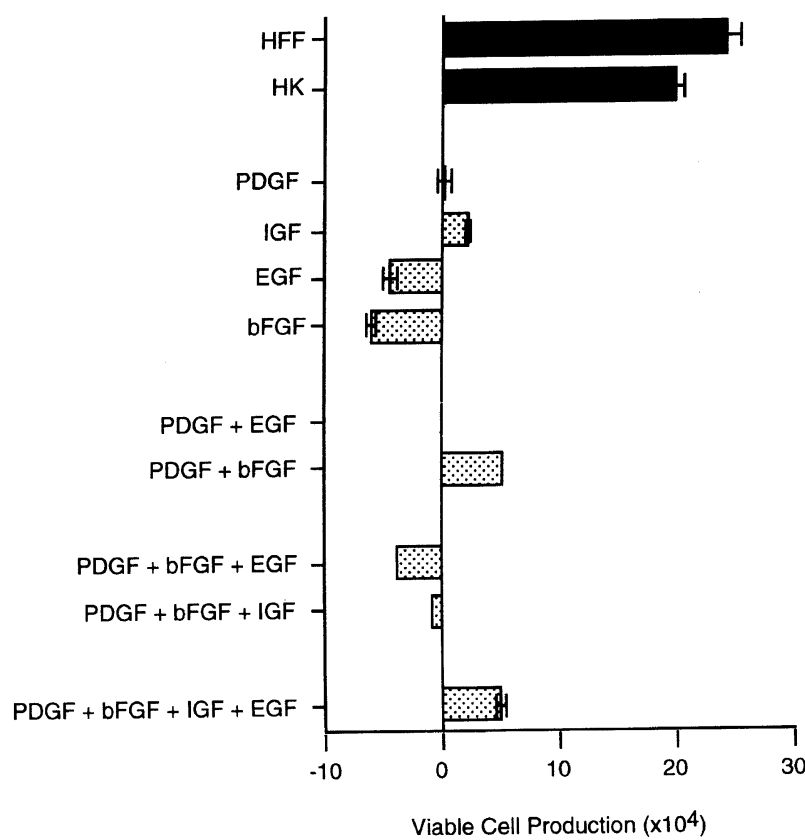

Figure 6 Effects of PDGF BB, IGF-I, EGF and bFGF on BL-cell population growth. L3055 cells were cultured for $72 \mathrm{~h}$ either alone, in direct contact with HFF or HK cells, or with the indicated cytokines (PDGF: $10 \mathrm{ng} / \mathrm{ml}$; IGF-I: $100 \mathrm{ng} / \mathrm{ml}$; bFGF: $100 \mathrm{ng} / \mathrm{ml}$; EGF: $10 \mathrm{ng} / \mathrm{ml}$ ). Net viable cell production was calculated as described in Materials and Methods. Means \pm S.D. of duplicate samples. Experiment representative of two similar

isms of relevance to $\mathrm{BL}$ in vivo. CD40-ligand-expressing cells, on the other hand, fail to promote BL-cell survival by pathways relevant to the natural biology of the tumour since CD40-ligand provides additional signals that promote BL-cell differentiation.

\section{Differential effects of exogenous cytokines on BL-cell survival}

In order to gain further information of possible relevance to the mechanisms of paracrine survival of BL cells in situ, L3055 cells were tested for their responses to a range of exogenous cytokines, either alone or in various combinations. PDGF, IGF-I, bFGF and EGF were chosen in the first instance since they have been tested by others for their capacity to inhibit cMyc-induced apoptosis (in fibroblasts). ${ }^{3}$ As shown in Figure 6, none of these cytokines was found to be capable of promoting substantial expansion in viable BL cell numbers, although small increases in tumour-cell productivity were observed with IGF-I alone, and with combinations of PDGF BB+bFGF with, or without, IGF-I and EGF. However, EGF and bFGF either alone or combined in the presence of PDGF BB appeared to promote apoptosis of BL cells (Figure 6).

A further panel of cytokines IL-1 $\beta$, IL-4, IL-6, IL-10, TNF$\alpha$ and GM-CSF (members of which may be considered relevant to germinal-centre B-cell survival or may be produced by tumour-infiltrating macrophages) was also tested for effects on BL-cell survival. The results, summarised in Figure 7, indicate that while IL-4, IL-10 and TNF- $\alpha$ each promoted low-level enhancement of viable

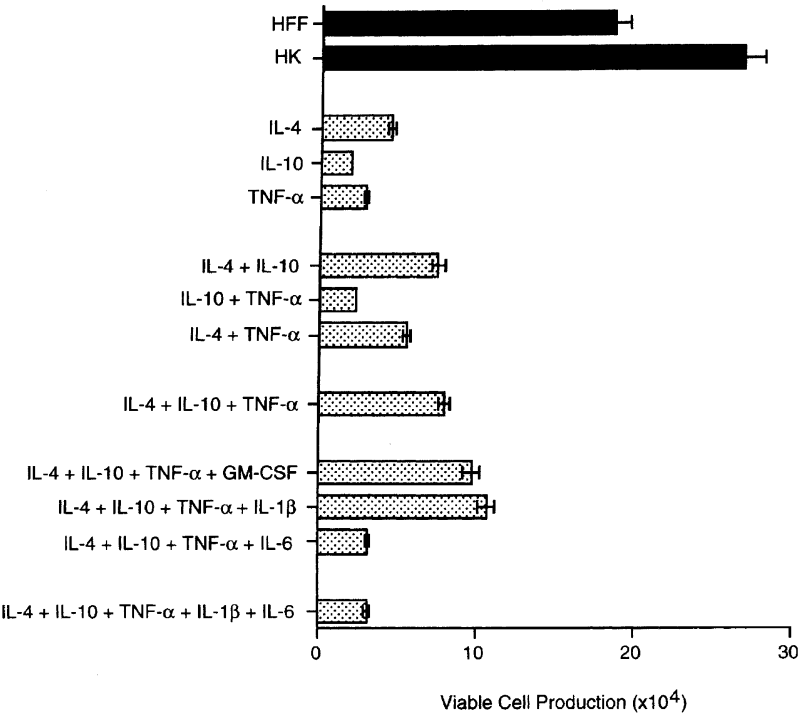

Figure 7 Effects of interleukins, TNF- $\alpha$ and GM-CSF on BL-cell population growth. L3055 cells were cultured for $72 \mathrm{~h}$ either alone, in direct contact with HFF or HK cells, or with the indicated cytokines (IL-1 $1: 0.1 \mathrm{ng} / \mathrm{ml}$; IL-4: $20 \mathrm{ng} /$ $\mathrm{ml}$; IL-6: $10 \mathrm{ng} / \mathrm{ml}$; IL-10: $5 \mathrm{ng} / \mathrm{ml}$; TNF- $\alpha$ : $5 \mathrm{ng} / \mathrm{ml}$; GM-CSF: $0.16 \mathrm{ng} / \mathrm{ml})$. Net viable cell production was calculated as described in Materials and Methods. Means \pm S.D. of duplicate samples. Experiment representative of three similar

tumour-cell productivity, the effect was doubled when the cytokines were combined. Inclusion of GM-CSF or IL-1 $\beta$ marginally improved yield of viable tumour cells, whereas inclusion of IL-6 markedly reduced the effect (Figure 7). In all cases, soluble factors that supported BL-cell survival failed to alter cell-surface phenotype or inhibit cell-cycle activity (data not shown).

\section{Macrophages affect BL-cell survival by multiple mechanisms}

It seems logical to predict that the removal of apoptotic BL cells by tumour-infiltrating macrophages is likely to be beneficial to the emerging tumour-cell population since apoptotic cells that become secondarily necrotic may have detrimental effects on their neighbours. Since monocytederived macrophages are known to phagocytose apoptotic group I BL cells, including L3055 cells, ${ }^{25-27}$ such activity may contribute significantly to the low level of apoptosis and high level of viable-cell productivity observed in L3055 populations co-cultured in contact with macrophages (Figure 3). However, macrophage support of BL cells is also provided by the activity of soluble factor(s) that function in the absence of any clearance effects (Figure 3). Neutralising mAbs to IL-10 and TNF- $\alpha$ fail to inhibit the soluble supportive activity of these macrophages (Figure 8) demonstrating that, while the macrophage-derived soluble factors IL-10 and TNF- $\alpha$ can protect $\mathrm{BL}$ cells from apoptosis, additional macrophagederived molecules are active in the present model. Indeed, the slight enhancement of viable-cell productivity in the presence of both anti-IL-10 and anti-TNF- $\alpha$ over that provided by macrophages alone (Figure 8 ) suggests that, in the context of additional macrophage-derived factors, IL-10 and TNF- $\alpha$ could display a combined inhibitory activity against BL cells. 
To determine whether macrophages that are actively engaged in phagocytosis of apoptotic BL cells also produce soluble factors that affect BL-cell survival, we compared the ability of macrophages cultured alone or with viable, apoptotic or necrotic BL cells to support L3055 cells in transwells. The results, shown in Figure 9, indicate that macrophages that have phagocytosed apoptotic cells are less effective in supporting L3055 cells than macrophages alone, or macrophages that have been co-cultured with mainly viable or necrotic cells. L3055 cells themselves failed to provide substantial support for L3055 cells in the transwells, although low-level support provided by viable BL cells was significantly greater than that provided by apoptotic or necrotic BL cells (Figure 9). Macrophages responding to LPS were at least as effective as untreated

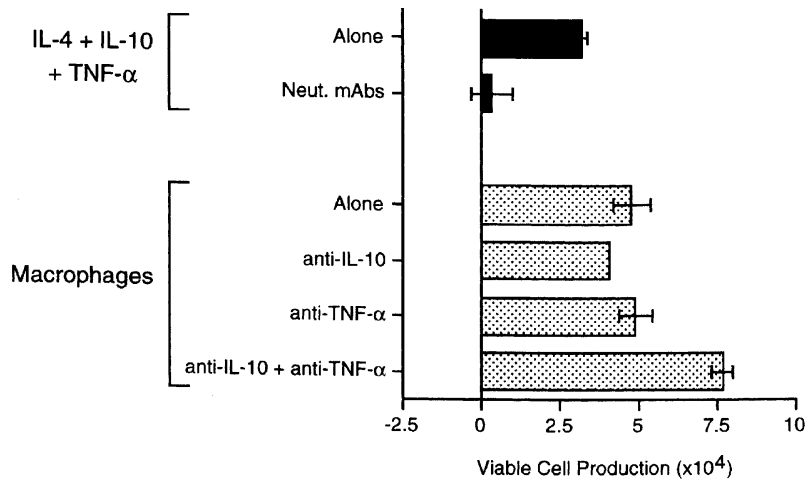

Figure 8 Effects of neutralising antibodies on macrophage-mediated support of BL-cell population growth. L3055 cells were cultured either in the presence of a mixture of IL-4, IL-10 and TNF- $\alpha$, or in direct contact with macrophages. The indicated individual neutralising antibodies, or a mixture of neutralising antibodies against IL-4, IL-10 and TNF- $\alpha$ ('Neut. mAbs'), were tested for their ability to affect net viable BL-cell production. Means \pm S.D. of duplicate samples. Experiment representative of two similar macrophages in producing soluble factors supporting L3055 cells.

Macrophages that have engaged in phagocytosis of apoptotic cells have been reported to produce TGF- $\beta$ which may function in an anti-inflammatory negative feedback loop to suppress macrophage pro-inflammatory cytokine production. ${ }^{21}$ We sought, therefore, to determine the effect of TGF- $\beta$ on BL-cell survival and productivity. As shown in Figure 10, TGF- $\beta$ was found to promote apoptosis (Figure $10 \mathrm{~A}$ ), and to abolish expansion (Figure 10B), of L3055 cells in a dose-dependent fashion (maximal at around $1 \mathrm{ng} / \mathrm{ml}$ ). Significantly the pro-apoptotic action of TGF- $\beta$ was dominant over the effect of the anti-apoptotic cytokines,

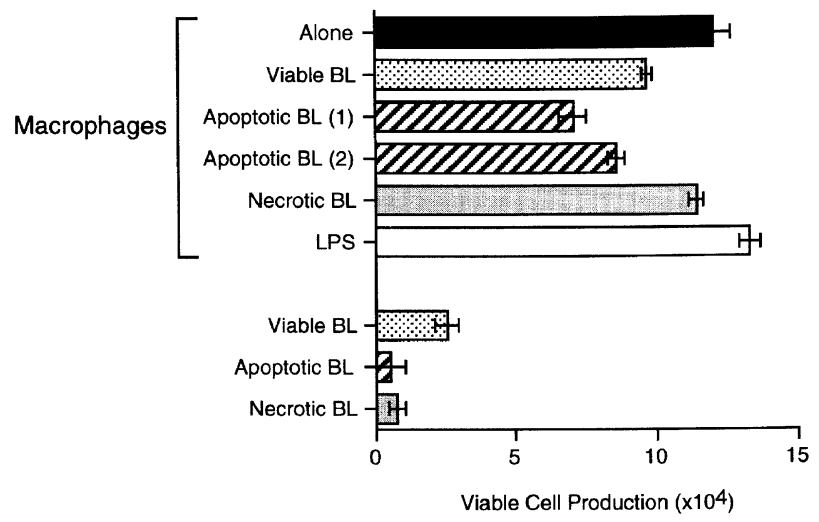

Figure 9 Support of BL cells by soluble factors released by macrophages cocultured with viable, apoptotic or necrotic BL cells, or LPS. L3055 cells were cultured for $48 \mathrm{~h}$ in transwells either over viable, apoptotic or necrotic L3055 cells, or over macrophages which had been untreated ('Alone') or pretreated with viable, apoptotic ('Apoptotic BL (2)'), or necrotic L3055 cells or LPS for $16 \mathrm{~h}$ prior to transwell addition, or with apoptotic L3055 cells ('Apoptotic BL (1)') immediately prior to transwell addition. Net viable cell production was calculated as described. Means \pm S.D. of duplicate samples. Experiment representative of three similar
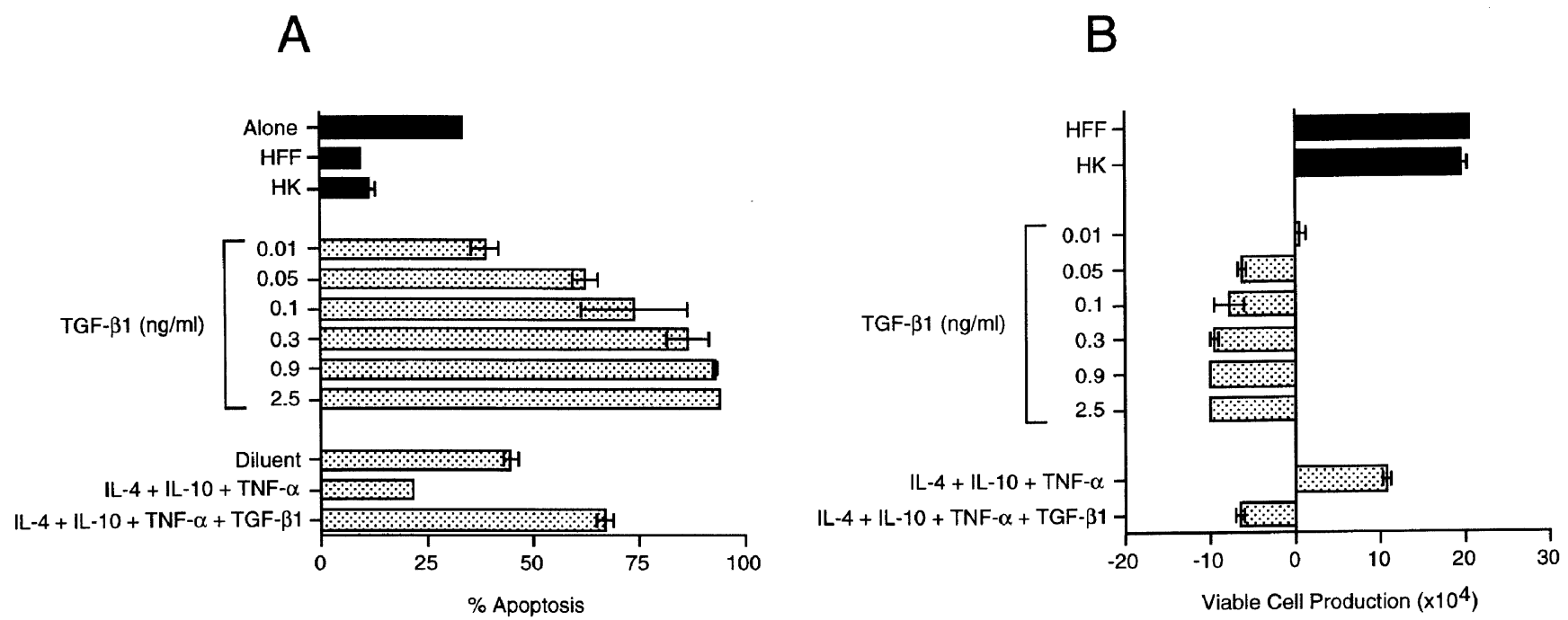

Figure 10 Effect of TGF- $\beta 1$ on BL-cell survival and growth. L3055 cells were cultured either alone, in direct contact with HFF or HK cells, or with the indicated concentrations of TGF- $\beta 1$, or with the combination of IL-4, IL-10 and TNF- $\alpha$ in the presence or absence of TGF- $\beta 1(0.1 \mathrm{ng} / \mathrm{ml})$. After $72 \mathrm{~h} \%$ apoptosis $(\mathbf{A})$ and net viable cell production (B) were assessed. Means \pm S.D. of duplicate samples. Experiment representative of two similar 
IL-4, IL-10 and TNF- $\alpha$ (Figure 10). Taken together, these results indicate that tumour-infiltrating macrophages can interact with BL cells both to promote, and to inhibit, tumour-cell survival.

\section{Discussion}

Little is known of the micro-environmental factors that may influence tumour-cell survival in BL, a B-cell malignancy in which tumour-cell numbers expand in the face of constitutive, high-rate apoptosis. In this study we have investigated the effects of a number of candidate micro-environmental factors in an established in vitro model of BL, the 'group I' cell line, the constituent cells of which, by many criteria, retain the phenotype of the tumour cells as they reside in vivo. We show that apoptosis in a group I BL line, L3055, which retains a high propensity to undergo 'spontaneous' apoptosis in vitro, can be modulated by multiple factors of potential relevance to the micro-environment of the tumour in vivo. We conclude that BLcell survival and net expansion of the tumour-cell population are promoted both by autocrine and by paracrine mechanisms. We identify soluble factors that function either to promote or to inhibit BL-cell survival and we show that one survival mechanism, that supported by CD40-ligation, probably has no in vivo relevance. Finally, we provide evidence to suggest that the tumour-infiltrating ('starry sky') macrophages of BL could influence the tumour-cell population by a combination of pro-apoptosis and anti-apoptosis mechanisms.

Autocrine/juxtacrine modes of B-cell survival and proliferation are well established ${ }^{28}$ and some of the underlying molecular mechanisms have been identified. For example, B-cell-derived CD23 acts to promote survival and growth of certain B-cell populations through binding to B-cell surface CD21 as well as other, as yet uncharacterised, receptors. ${ }^{29-31}$ In addition, B-cell population survival may be enhanced through ligation of B-cell CD40 by autocrine CD40L. ${ }^{32}$ These mechanisms are unlikely to apply to the present model since (1) group I BL cells, while they express CD21, produce little or no CD23, and (2) ligation of CD40 on group I BL cells alters their phenotype. Further work will be required to identify the additional autocrine mechanisms observed here which support survival of $\mathrm{BL}$ cells with retention of the group I phenotype. One candidate mechanism may involve interferon- $\alpha$, a cytokine produced by BL cells that promotes BL-cell survival without appearing to alter the group I phenotype. ${ }^{33}$ Whatever their nature, it is obvious that without these mechanisms it would not be possible to maintain group I BL lines in vitro.

Additional BL-cell survival mechanisms are likely to be provided by non-malignant elements of the tumour. Here we have considered possible paracrine mechanisms mediated both by direct 'feeder'-cell/tumour-cell interactions and by soluble factors. We considered fibroblasts, follicular dendritic cells (since BL is a malignancy of germinal centre B-cell origin ${ }^{5}$ ) and macrophages which constitute the major non-malignant cell component of BL. ${ }^{34}$ In addition, we assessed the effects of the activated T-cell surface molecule CD40-ligand since activated $\mathrm{T}$ cells are also known to infiltrate $\mathrm{BL}^{23}$ and CD40-ligation is known to generate anti-apoptosis signals in $\mathrm{BL}$ cells. ${ }^{35-37}$ CD40mediated survival, however, was also accompanied by gross phenotypic changes, including CD54 and CD95 upregulation along with cell-growth arrest, comparable with observations in other studies in which ligation of CD40 on $\mathrm{BL}$ cells was achieved either by T-cell-anchored or soluble CD40L or by anti-CD40 antibody. ${ }^{37,38}$ It has been noted that a threshold in the level of CD40 ligation determines phenotypic changes in $\mathrm{B}$ cells. ${ }^{39}$ Our results indicate that ligation of CD40, achieved by multiple mechanisms (cellbound and soluble natural ligand as well as agonist antibody) consistently alters the group I phenotype of BL and therefore is unlikely to provide a constant pro-survival mechanism in the tumour environment.

Of greater relevance to the biology of $\mathrm{BL}$ are our findings that fibroblasts, the follicular dendritic cell-derived line HK and macrophages, together with the cytokines IL-4, IL-10 and TNF- $\alpha$, each substantially promoted BL-cell survival and tumour-cell yield with retention of the group I phentoype. These results confirm and extend earlier observations that irradiated fibroblasts supply survival factor(s) to BL cells without up-regulating Bcl-2 expression. ${ }^{40}$ Furthermore, our observations point to several paracrine pro-survival mechanisms that could contribute to the micro-environment in BL. These mechanisms include (1) undefined direct cell/cell contacts with fibroblasts, HK cells and macrophages (2) undefined soluble factors derived from these cells and (3) defined soluble factors from $T$ cells (IL-4) and macrophages (IL-10 and TNF- $\alpha$ ). There may be overlap in the mechanisms underlying (1) and (2) above since the undefined soluble factors observed here appeared to operate over short range. Regardless of this the undefined survival mechanisms could involve cytokines, cytokine mixtures or cell-surface-associated factors in addition to those tested here. Alternatively or additionally, BL-cell survival and tumour-cell yield may be supported by markedly different mechanisms. For example 'feeder' cells may stimulate biosynthesis of anti-oxidants such as glutathione that have proven pro-survival effects on $\mathrm{BL}$ cells ${ }^{41}$ or they may mediate phagocytic removal of apoptotic tumour cells which could otherwise have detrimental effects on their neighbours. In the present context, survival and net expansion of BL populations may be supported not only by the 'professional' phagocytic activity of macrophages (which have proven ability to phagocytose effectively apoptotic BL cells ${ }^{25,27}$ ) but also by the potential 'amateur' phagocytic activity of fibroblasts and HK cells. While the potential of $\mathrm{HK}$ cells to phagocytose apoptotic cells has not been investigated, fibroblasts have known ability to phagocytose apoptotic cells, ${ }^{42}$ including BL cells (CD Gregory, 1999 unpublished observations).

The biological activity of macrophages infiltrating $\mathrm{BL}$ has not been studied as far as we are aware. Here we have considered several macrophage functions that might be relevant in $\mathrm{BL}$. We show that the macrophage-derived proinflammatory cytokine TNF- $\alpha$ has supportive activity for the tumour cells, particularly in combination with IL-10, an antiinflammatory cytokine which has been found by some ${ }^{43}$ (though not by others ${ }^{21}$ ) to be produced by macrophages 
that have engulfed apoptotic cells. We observed that macrophages engaged in phagocytosis of apoptotic BL cells produced soluble factors that were less supportive for the tumour cells than those produced by untreated macrophages or macrophages co-cultured with viable $\mathrm{BL}$ cells, necrotic BL cells or LPS. Furthermore, we found that TGF- $\beta 1$, which is known to be produced by macrophages that have engulfed apoptotic cells and which can suppress macrophage pro-inflammatory responses, ${ }^{21}$ potently promotes apoptosis in $\mathrm{BL}$ cells, including those cells supported by IL- $4, \quad \mathrm{IL}-10$ and TNF- $\alpha$, probably via a mechanism involving cell cycle conflict (G1-arresting signals in the face of de-regulated $c-m y c) .{ }^{44}$ These results predict that tumourinfiltrating macrophages with a pro-inflammatory phenotype would be more supportive toward the malignant cells than macrophages with an anti-inflammatory phenotype, although in the present system macrophages of either category supported net tumour-cell growth to a greater or lesser degree. In addition, since certain EBV-positive BL lines fail to growth-arrest following exposure to TGF- $\beta 1,{ }^{45,46}$ our results suggest that the 'anti-inflammatory' macrophage phenotype may have differential effects on EBV-positive versus EBV-negative BL.

In conclusion, this study has taken the first steps in identifying factors which may function in the microenvironment of BL to promote net growth of a tumour population that retains a high propensity to undergo apoptosis. We identify several mechanisms of potential relevance to $\mathrm{BL}$ growth in vivo. Significantly, our results suggest that tumour-infiltrating macrophages may provide both positive and negative effects on net tumour growth and highlight the need for further studies focused on macrophage/tumour-cell interactions in BL. It will be important to determine the phenotypes of the macrophages in situ and the ways in which they are affected by the tumour cells. For example, are they involved in the impairment of anti-tumour cell-mediated immune responses? A detailed understanding of such macrophage/tumour-cell interactions may yield important information for the development of novel antitumour therapeutic strategies.

\section{Materials and Methods Cells}

All cell lines were routinely cultured in suspension in RPMI 1640 medium (Gibco) containing 10\% Serum Supreme (BioWhittaker). L3055 cells are EBV-negative and carry the $t(8 ; 14)$ translocation. ${ }^{47}$ Although the group I BL surface phenotype $\left(\mathrm{CD} 10^{+} \mathrm{CD} 23^{-} \mathrm{CD} 39^{-}\right.$ $\left.C D 77^{+}\right)$- that of the freshly isolated biopsy cells - was originally described for EBV-positive BL, it can also be applied to EBV-negative cells. ${ }^{7,47}$ L3055 cells have been previously classified as group I and are also Bcl-2-negative. ${ }^{13,47}$ This phenotype was confirmed here using established immuno-phenotyping methods. ${ }^{13,47}$ Cells were used in early passage $(<50)$ only. Stable Bcl-2 transfectants were obtained as described. ${ }^{48}$ Human foetal skin fibroblasts were subcultured using trypsin/EDTA (Gibco) and used between passage 8 and 25. The follicular dendritic cell-like line $\mathrm{HK}^{22}$ was obtained from Dr. Y Choi (Alton Ochsner Medical Foundation, New Orleans) and subcultured using trypsin/EDTA. L cells expressing CD40L, ${ }^{24}$ together with their parental counterparts, were obtained from Dr. J Banchereau,
Schering Plough, Lyon and subcultured using $0.02 \%$ EDTA. L cells were irradiated (7000 rads) before use in experiments. Macrophages were obtained by culture of human monocytes isolated by Percoll fractionation of de-fibrinated venous blood as described. ${ }^{25,27}$ Adherent cells (>99\% monocytes at the start of the culture period ${ }^{25}$ ) were maintained for 7 days in IDMEM (Gibco) containing $10 \%$ heat-inactivated autologous serum.

\section{Autocrine culture}

L3055 cells were pre-incubated for $24 \mathrm{~h}$ in RPMI containing 1\% Serum Supreme, subsequently seeded at the indicated cell densities in $1 \%$ Serum Supreme in $25 \mathrm{~cm}^{2}$ tissue culture flasks (Nunc, Life Technologies) and incubated for $72 \mathrm{~h}$ at $37^{\circ} \mathrm{C}$. Of each pair of duplicate flasks, one was incubated horizontally with cells on the $25 \mathrm{~cm}^{2}$ surface, the other vertically with the cells on the $7.6 \mathrm{~cm}^{2}$ surface. Alternatively the $\mathrm{L} 3055$ cells were seeded into duplicate $96-$ well plates (Nunc, Life technologies) with either flat or round-bottomed wells and were incubated in $10 \%$ Serum Supreme for $96 \mathrm{~h}$ at $37^{\circ} \mathrm{C}$. In some experiments $\mathbf{L} 3055$ cells were cultured in transwells above viable, apoptotic, or necrotic L3055 cells (10\%/well). Apoptosis was induced by cold-shock ${ }^{20}$ and necrosis by heat shock. ${ }^{27}$

\section{Paracrine culture}

L3055 cells were co-cultured with fibroblasts, HK cells, L cells, or macrophages either in $25 \mathrm{~cm}^{2}$ tissue culture flasks or in 24-well plates (Nunc). In flasks, fibroblasts and HK cells were used at approximately $75 \%$ confluence; $L$ cells were seeded at $4 \times 10^{6}$ per flask followed by removal of non-adherent cells. L3055 cells were added in RPMI containing $10 \%$ Serum Supreme $\left(10 \mathrm{ml}, 2 \times 10^{5}\right.$ per $\left.\mathrm{ml}\right)$ and incubated for $72 \mathrm{~h}$ at $37^{\circ} \mathrm{C}$. In wells, L3055 cells were cultured for $48-96 \mathrm{~h}$ either in direct contact $\left(10^{5}\right.$ cells per well in $1.25 \mathrm{ml}$ ) with fibroblasts, HK cells or macrophages, or were separated from them using Millicell-CM (Millipore) inserts containing Biopore membranes with pore size of $0.4 \mu \mathrm{m}\left(10^{5}\right.$ cells per insert in $0.5 \mathrm{ml}$ with $0.75 \mathrm{ml}$ of medium below the insert). Cytokines were added at concentrations indicated in the Figure legends. Where neutralising antibodies were used, they were incorporated at doses known to neutralise $>90 \%$ of the effects of the requisite cytokines. In some experiments, macrophages were incubated with $10^{5}$ viable, apoptotic or necrotic BL cells or with LPS $(5 \mathrm{ng} / \mathrm{ml})$. Apoptosis and necrosis were induced as described above.

\section{Assessment of apoptosis and cell production}

Harvested cells were fixed in $2 \%$ Formaldehyde (Analar, BDH). Apoptosis was assessed either by fluorescence microscopy of acridine orange-stained samples ${ }^{11}$ or by flow cytometric light scatter analysis of unstained samples ${ }^{49}$ using either the Becton Dickinson FacScan or the Coulter XL flow cytometer. Total cell counts were obtained from the number of cellular events gathered using the $40 \mu \mathrm{l}$ volume stop on the Coulter XL. Viable cell counts were obtained from the number of events in the viable light scatter zone as described. ${ }^{49}$ Net production of viable cells was subsequently calculated by subtracting the viable cell count of untreated L3055 cells from the viable cell count of treated L3055 cells.

\section{Soluble factors and neutralising antibodies}

PDGF BB, IGF-1, bFGF, IL-1 $\beta$, IL-4, IL-6, IL10 and TNF- $\alpha$ were obtained from R\&D Systems (Abingdon, UK). GM-CSF and TGF- $\beta 1$ were obtained from Peprotech (London, UK). EGF was from Upstate 
Biotechnology (TCS Biologicals, Buckingham, UK). Neutralising polyclonal goat antibodies against IL-10 and TNF- $\alpha$ were purchased from R\&D Systems. Neutralising polyclonal rabbit anti-IL-4 was from Peprotech.

\section{Expression of surface antigens and $\mathrm{Bcl}-2$}

Indirect immunofluorescence staining of cell surface antigens was carried out on unfixed cells as previously described ${ }^{25}$ using saturating concentrations of primary antibodies and relevant FITC-conjugated secondary antibodies for visualisation. Bcl-2 staining was performed on ethanol-fixed cells. ${ }^{33}$ The following mouse IgG mAbs were used: 55 (CD10), BU17 (CD11a), MHM6 (CD23), AC2 (CD39), S2C6 (CD40), BU49 (CD49d) and anti-Bcl-2 (Dako), all visualised using goat antimouse IgG-FITC (Sigma). N3D4 (CD54) and CH11 (CD95, Upstate Biotechnology) are mouse lgM mAbs which were visualised using goat anti-mouse IgM-FITC (Southern Biotechnology Associates). 38.13 is rat $\operatorname{lgM} \mathrm{mAb}$ which was visualised using goat anti-rat IgM-FITC (Southern Biotechnology Associates). Immunofluorescence profiles were analyzed using the Coulter XL flow cytometer. Light scatter properties were used to gate viable and apoptotic cells as described. ${ }^{49}$

\section{Cell cycle analysis}

Cells were fixed in PBS containing $1 \%$ paraformaldehyde and $0.1 \%$ Triton X-100 and stained with propidium iodide $(20 \mu \mathrm{g} / \mathrm{ml})$. Histograms were obtained using the Coulter $\mathrm{XL}$.

\section{Acknowledgements}

We thank Dr. Jacques Banchereau for the CD40L L cells, Dr. John Pound for the irradiation protocol, Dr. Yong Sung Choi for the HK cell line and lan Ward for technical assistance. This work was supported by the Leukaemia Research Fund (UK).

\section{References}

1. Evan $G$ and Littlewood T (1998) A matter of life and cell death. Science 281 : $1317-1322$

2. Evan Gl, Wyllie AH, Gilbert CS, Littlewood TD, Land H, Brooks M, Waters CM, Penn LZ and Hancock DC (1992) Induction of apoptosis in fibroblasts by c-myc protein. Cell 69: 119-128.

3. Harrington EA, Bennett MR, Fanidi A and Evan GI (1994) C-myc-induced apoptosis in fibroblasts is inhibited by specific cytokines. EMBO J. 13: $3286-$ 3295

4. Magrath I (1990) The pathogenesis of Burkitt's lymphoma. Adv. Cancer Res. 55: $133-270$

5. Gregory CD, Tursz T, Edwards CF, Tetaud C, Talbot M, Caillou B, Rickinson AB and Lipinski M (1987) Identification of a subset of normal B cells with a Burkitt'sIymphoma (BL)-like phenotype. J. Immunol. 139: 313-318

6. Chapman CJ, Zhou JX, Gregory C, Rickinson AB and Stevenson FK (1996) $V_{H}$ and $V_{L}$ gene analysis in sporadic Burkitts lymphoma shows somatic hypermutation, intraclonal heterogeneity, and a role for antigen selection. Blood 88: 3562-3568

7. Rowe M, Rowe DT, Gregory CD, Young LS, Farrell PJ, Rupani H and Rickinson AB (1987) Differences in B-cell growth phenotype reflect novel patterns of Epstein-Barr virus latent gene expression in Burkitt lymphoma cells. EMBO J. 6 : 2743-2751

8. Gregory CD, Rowe M and Rickinson AB (1990) Different Epstein-Barr virus-Bcell interactions in phenotypically distinct clones of a Burkitt's lymphoma cell line. J. Gen. Virol. 71: 1481-1495

9. Liu YJ, Mason DY, Johnson GD, Abbot S, Gregory CD, Hardie DL, Gordon J and Maclennan ICM (1991) Germinal center cells express bcl-2 protein after activation by signals which prevent their entry into apoptosis. Eur.J. Immunol. 21: $1905-1910$
10. Henderson S, Rowe M, Gregory C, Croom-Carter D, Wang F, Longnecker R, Kieff $E$ and Rickinson A (1991) Induction of bcl-2 expression by Epstein-Barr virus latent membrane protein 1 protects infected $B$ cells from programmed cell death. Cell 65: 1107-1115

11. Gregory CD, Dive C, Henderson S, Smith CA, Williams GT, Gordon J and Rickinson AB (1991) Activation of Epstein-Barr virus latent genes protects human $B$ cells from death by apoptosis. Nature 349 : $612-614$

12. Maclennan ICM (1994) Germinal-centers. Annu. Rev. Immunol. 12: 117-139

13. Milner AE, Grand RJA, Waters CM and Gregory CD (1993) Apoptosis in Burkitt lymphoma cells is driven by c-myc. Oncogene 8: $3385-3391$

14. O'Conor GT (1961) Malignant lymphoma in African children. II. Pathological entity. Cancer 14: 270-283

15. Epstein MA and Herdson PB (1963) Cellular degeneration associated with characteristic nuclear fine structure changes in the cells from two cases of Burkitt's malignant lymphoma syndrome. Br. J. Cancer 17: 56-58

16. Cooper EH, Frank GL and Wright DH (1966) Cell proliferation in Burkitt tumours. Eur J. Cancer 2: 377-384

17. Berard C, O'Conor GT, Thomas LB and Torloni H (1969) Histopathological definition of Burkitt's tumour. Bull. World Health Org. 40: 601-607

18. Van den Eijnde SM, Boshart L, Reutelingsperger CPM, De Zeeuw $\mathrm{Cl}$ and Vermeij-Keers C (1997) Phosphatidylserine plasma membrane asymmetry in vivo: A pancellular phenomenon which alters during apoptosis. Cell Death Differ. 4: $311-316$

19. Savill J. The innate immune system: recognition of apoptotic cells. In: Gregory CD (ed) Apoptosis and the Immune Response. New York: Wiley-Liss, 1995, pp. $341-369$

20. Gregory CD and Milner AE (1994) Regulation of cell survival in Burkittlymphoma: Implications from studies of apoptosis following cold-shock treatment. Int. J. Cancer 57: 419-426

21. Fadok VA, Bratton DL, Konowal A, Freed PW, Westcott JY and Henson PM (1998) Macrophages that have ingested apoptotic cells in vitro inhibit proinflammatory cytokine production through autocrine/paracrine mechanisms involving TGF- $\beta$, PGE2, and PAF. J. Clin. Invest. 101: 890-898

22. Kim H-S, Zhang XH and Choi YS (1994) Activation and proliferation of follicular dendritic cell-like cells by activated Tlymphocytes. J. Immunol. 153: 2951-2961

23. Rooney $\mathrm{CM}$, Gregory $\mathrm{CD}$, Rowe M, Finerty S, Edwards C, Rupani $\mathrm{H}$ and Rickinson AB (1986) Endemic Burkitt's lymphoma-phenotypic analysis of tumor biopsy cells and of derived tumor cell lines. J. Natl. Cancer Inst. 77:681687

24. Garrone P, Neidhardt EM, Garcia E, Galibert L, Vankooten C and Vanchereau J (1995) Fas ligation induces apoptosis of CD40-activated human B lymphocytes. J Exp. Med. 182: 1265-1273

25. Flora PK and Gregory CD (1994) Recognition of apoptotic cells by human macrophages-inhibition by a monocyte/macrophage-specific monoclonal antibody. Eur. J. Immunol. 24: 2625-2632

26. Flora PK, Devitt A, Johnson GD, Milner AE and Gregory CD (1996) Bcl-2 delays macrophage engulfment of human $B$ cells induced to undergo apoptosis. Eur. J. Immunol. 26: 2243-2247

27. Devitt A, Moffatt OD, Raykundalia C, Capra JD, Simmons DL and Gregory CD (1998) Human CD14 mediates recognition and phagocytosis of apoptotic cells. Nature 392: 505-509

28. Gordon J and Cairns JA (1991) Autocrine regulation of normal and malignant $B$ lymphocytes. Adv. Cancer Res. 56: 313-334

29. Aubry JP, Pochon S, Graber P, Jansen KU and Bonnefoy JY (1992) CD21 is a ligand for $\mathrm{CD} 23$ and regulates IgE production. Nature 358: 505-507

30. Bonnefoy JY, Henchoz S, Hardie D, Holder MJ and Gordon J (1993) A subset of anti-CD21 antibodies promote the rescue of germinal center b-cells from apoptotis. Eur. J. Immunol. 23: 969-972

31. White LJ, Ozanne BW, Graber P, Aubry JP, Bonnefoy JY and Cushley W (1997) Inhibition of apoptosis in a human pre-B-cell line by $\mathrm{CD} 23$ is mediated via a novel receptor. Blood 90: 234-243

32. Grammer AC, Bergman MC, Miura Y, Fujita K, Davis LS and Lipsky PE (1995) The CD40 ligand expressed by human B cells costimulates B-cell responses. J. Immunol. 154: 4996-5010

33. Milner AE, Johnson GD and Gregory CD (1992) Prevention of programmed cell death in Burkitt lymphoma cell lines by bcl-2-dependent and bcl-2-independent mechanisms. Int. J. Cancer 52: 636-644

34. Wright DH (1963) Cytology and histochemistry of the Burkitt lymphoma. Br. J. Cancer 17: 50-55 
35. Holder MJ, Wang H, Milner AE, Casamayor M, Armitage R, Spriggs MK, Fanslow WC, MacLennan ICM, Gregory CD and Gordon J (1993) Suppression of apoptosis in normal and neoplastic human B lymphocytes by CD40 ligand is independent of Bcl-2 induction. Eur. J. Immunol. 23: 2368-2371

36. Walker A, Taylor ST, Hickman JA and Dive C (1997) Germinal center-derived signals act with $\mathrm{Bcl}-2$ to decrease apoptosis and increase clonogenicity of drugtreated human B lymphoma cells. Cancer Res. 57: 1939-1945

37. Baker MP, Eliopoulos AG, Young LS, Armitage RJ, Gregory CD and Gordon J (1998) Prolonged phenotypic, functional, and molecular change in group I Burkitt lymphoma cells on short-term exposure to CD40 ligand. Blood 92: 2830-2843

38. Schattner EJ, Elkon KB, Yoo DH, Tumang J, Krammer PH, Crow MK and Friedman SM (1995) CD40 ligation induces Apo-1/Fas expression on human B lymphocytes and facilitates apoptosis through the Apo-1/Fas pathway. J. Exp. Med. 182: 1557-1565

39. McCloskey N, Pound JD, Holder MJ, Williams JM, Roberts LM, Lord JM and Gordon J (1999) The extrafollicular-to-follicular transition of human B lymphocytes: induction of functional globotriaosylceramide (CD77) on high threshold occupancy of CD40. Eur. J. Immunol. 29: 3236-3244

40. Falk MH, Hultner L, Milner A, Gregory CD and Bornkamm GW (1993) Irradiated fibroblasts protect Burkitt-lymphoma cells from apoptosis by a mechanism independent of bcl-2. Int. J. Cancer 55: 485-491

41. Falk MH, Meier T, Issels RD, Brielmeier M, Scheffer B and Bornkamm GW (1998) Apoptosis in Burkitt lymphoma cells is prevented by promotion of cysteine uptake. Int. J. Cancer 75: 620-625

42. Hall SE, Savill JS, Henson PM and Haslett C (1994) Apoptotic neutrophils are phagocytosed by fibroblasts with participation of the fibroblast vitronectin receptor and involvement of a mannose/fucose-specific lectin. J. Immunol. 153: $3218-3227$
43. Voll RE, Herrmann M, Roth EA, Stach C, Kalden JR and Girkontaite I (1997) Immunosuppressive effects of apoptotic cells. Nature 390: 350-351

44. Macdonald I, Wang H, Grand R, Armitage RJ, Fanslow WC, Gregory CD and Gordon J (1996) Transforming growth factor- $\beta 1$ cooperates with antiimmunoglobulin for the induction of apoptosis in group I (biopsy-like) Burkitt lymphoma cell lines. Blood 87: 1147-1154

45. Kumar A, Rogers T, Maizel A and Sharma S (1991) Loss of transforming growth factor beta-1 receptors and its effects on the growth of EBV-transformed human $B$ cells. J. Immunol. 147: 998-1006

46. Piacebello W, Severino A, Stacchini A and Aglietta M (1991) Differential effect of transforming growth factor-beta-1 on the proliferation of human lymphoid and myeloid-leukemia cells. Haematologica 76: 460-466

47. Milner AE, Grand RJA, Vaughan ATM, Armitage RJ and Gregory CD (1997) Differential effects of $B C L-2$ on survival and proliferation of human B-lymphoma cells following gamma-irradiation. Oncogene 15: 1815-1822

48. Wang H, Grand RJA, Milner AE, Armitage RJ, Gordon J and Gregory CD (1997) Repression of apoptosis in human B-lymphoma cells by CD40-ligand and Bcl-2: relationship to the cell-cycle and role of the retinoblastoma protein. Oncogene 13 : 373-379

49. Dive C, Gregory CD, Phipps DJ, Evans DL, Milner AE and Wyllie AH (1992) Analysis and discrimination of necrosis and apoptosis (programmed cell death) by multiparameter flow cytometry. Biochim. Biophys. Acta 1133: 275-285 